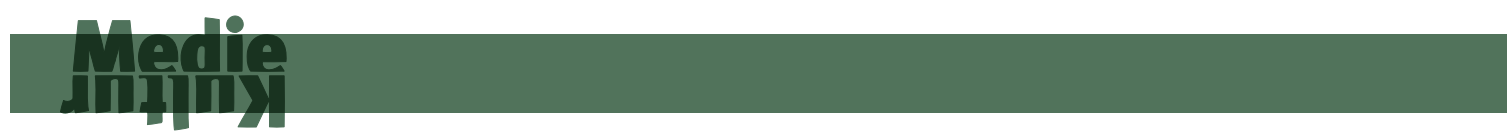

MedieKultur | Journal of media and communication research | ISSN 1901-9726

Book Review

\title{
Kirsten Drotner, Christina Papsø Weber, Berit Anne Larsen and Anne Sophie Warberg Løssing (red.): \\ Det interaktive museum. \\ Frederiksberg: Samfundslitteratur. 2011.
}

\author{
Connie Svabo
}

MedieKultur 2013, 54, 200-202

\begin{abstract}
Published by SMID | Society of Media researchers In Denmark | www.smid.dk The online version of this text can be found open access at www.mediekultur.dk
\end{abstract}

Antologien Det interaktive museum er en akademisk publikation skrevet af danske og udenlandske forfattere og målrettet grundfagsstuderende på universiteter, seminarier og højskoler. Foruden redaktørernes introduktionskapitel "Interaktive museer: hvordan og hvorfor?", består bogen af fem kapitler i del 1: "Materialer i bevægelse", og fire kapitler i del 2: "Organisationer i bevægelse". Seks ud af ni kapitler beskæftiger sig med danske museer og er fra danske bidragydere, men i bogen findes også tre oversatte bidrag fra internationale museumseksperter, hvoraf de to er oversatte versioner af tidligere publiceret materiale.

Det interaktive museum beskæftiger sig med museet som kommunikerende institution, og det er således museernes formidlings- og udstillingspraksis, der er afsæt for bogens fokus på interaktion. Interaktion forstås som en udveksling mellem museerne som institutioner og det omgivende samfund, og som en udveksling mellem museerne og deres aktuelle og mulige publikum. Mest repræsenteret i bogen er den sidstnævnte gradbøjning, hvor interaktion ses som en kommunikativ udveksling, der omfatter samspil mellem publikum, genstande og kommunikationsmaterialer som tekstplancher, kataloger, måske lyd og film, samt medbesøgende og fagpersoner som omvisere, besøgspiloter, kustoder og billetsælgere.

Det er relevant at beskæftige sig med det interaktive museum, fordi der er sket nogle ændringer i museernes udveksling med publikum og kommunikation med det omgivende samfund. Den kommunikative relation mellem samling, institution og brugere er forandret, og dette udfoldes i bogen i forhold til to temaer: forekomsten af nye interaktionsformer qua digitale medier samt nye deltagerorienterede og participatoriske formål med 
interaktionen. Temaerne er udtryk for to strømninger, der brydes i antologien. Den ene strømning er det overvejende fokus på digitale medier, hvor tanken er, at kombinationen af den personlige computer, mobiltelefonen og internettet er med til at ændre muligheden for kontakt mellem museer og aktuelle og potentielle brugere. Den anden strømning handler om brugeroplevelser, inddragelse af nye brugere, dialog og deltagelse, og er en del af en bredere ny museologisk tænkning, der vægter museets sociale ansvar og rolle som publikumsrettet institution.

Der har i den første begejstring over nye digitale medier været en tendens til at kæde disse to strømninger sammen - for eksempel ved at sætte lighedstegn mellem digital mediering og participatoriske museumsinteraktioner. Der har været en stor tiltro til, at digitale teknologier kunne alt muligt - også skabe særlige nye deltagelsesformer på museerne. Det var "[...] en tankegang, som gjorde teknologien i sig selv til gud, mens den ignorerede ethvert bevis på, at det modsatte også kunne være tilfældet" (Samis \& Pau, p. 156). Digitale medier blev set som en direkte vej til brugerinvolvering og -deltagelse.

Imidlertid viser de tidlige tiltag med digitalt medierede interaktioner mellem publikum og udstillinger, at der ikke er noget automatisk forhold mellem digital teknologi og participation, og en række af bogens kapitler stiller også spørgsmål ved denne automatiske sammenkædning, og bidrager således til at kvalificere forståelsen af forholdet mellem digital mediering og deltagelse (for eksempel Mortensen \& Vestergaard, Littrup \& Thelle, Rudloff, Samis \& Pam, Larsen \& Løssing).

Rudloff skriver eksempelvis: "[...] selvom en tese om nye medier er, at de i særlig grad kan anvendes til at nå underrepræsenterede brugergrupper af museer, fordi de kan møde brugerne på andre steder og måder end inden for det traditionelle museums fire vægge" ( $f x$ Kyed m.fl. 2006, p. 26), ved vi i virkeligheden endnu relativt lidt om, hvordan de nye digitale formidlingsformer lever op til målsætningerne om øget og mere engagerende brugerinvolvering (Rudloff, p. 80).

Ligeledes skriver Larsen \& Løssing om digital mediering og kunstformidling til unge: "Det er med andre ord ikke tilstrækkeligt blot at skrue op for den digitale formidling og tilstedeværelsen på de sociale medier, hvis man vil nå den unge målgruppe. Tværtimod udtrykker de unge informanter først og fremmest et ønske om at føle sig adresseret af formidlingens indhold, mens den konkrete platform reelt kommer i anden række. De digitale tiltag skal således have et synligt formål og tilføre formidlingen en åbenlys merværdi, hvis de skal have en berettigelse" (Larsen \& Løssing, p. 187).

Der tegner sig et billede, hvor deltagelse og digital mediering måske nok i udgangspunktet tænkes som sammenhængende størrelser - og selv på bogens bagside iscenesættes digitale medier som en "afgørende katalysator" for ændrede interaktioner med publikum - men hvor nærstudierne af besøgendes interaktioner med udstillinger og digitale medier, viser, at digitale formidlingsteknologier ikke automatisk medfører dialog og deltagelse, og at dialog og deltagelse ikke er bundet op på digitale formidlingsteknologier. 
Tværtimod. Men mere om det om lidt, for først en mulig forklaring på, hvorfor idealer om inddragelse kædes sammen med digitale medier: Forklaringen kan ifølge Simon findes i webmediernes stærke participatoriske elementer.

Udviklingen af de sociale netværksteknologier i midten af 2000'erne ændrede brugerinddragelse fra at være noget begrænset og sjældent til noget, der er muligt for alle når som helst og hvor som helst. Vi blev en del af det, som medieforskeren Henry Jenkins kalder en 'konvergenskultur' (Jenkins 2006), hvor almindelige mennesker, ikke blot kunstnere eller akademikere, tager kulturelle genstande og materialer og herudfra skaber egne afledte værker eller diskussioner (Simon, p. 124).

Ifølge Simon baner webbaseret deltagelse vejen for at tænke deltagelse ind $i$ andre former for kulturel aktivitet, for eksempel i de fysiske miljøer på museer, biblioteker og kulturhuse. Interessant nok skal deltagelse på disse steder dog ikke nødvendigvis foregå via digital mediering. Simon fremhæver en række eksempler på vellykket kulturinstitionsbaseret deltagende interaktion. Ingen af disse eksempler er digitalt medierede: kategorisering af bøger på et bibliotek ved hjælp af placering af afleverede bøger på særlige hylder; afstemning om udstillingspræferencer vha badges; workshopbaserede klimakonferencer; fremstilling af low-tech plakater i forbindelse med en udstilling om rockmusik.

Deltagelse i fysiske miljøer som museer skal ikke nødvendigvis medieres digitalt. Det digitale nedtones også i bidraget fra Samis og Pau: "Så sent som i 2008 viste en undersøgelse af de besøgende på SFMOMA, at 78-90 pct. af de besøgende læser en udstillings vægtekster, mens et langt mindre antal benytter computerstande eller audiobaserede guider $\mathrm{i}$ deres mangeartede og foranderlige former" (Samis \& Pau, p. 156).

Formidling handler om brug af både analoge og digitale formidlingsredskaber. Der skal være fokus på de besøgendes behov, og Samis og Pau fremhæver, at deres bedste og mest relevante 'værktøjer' i udvikling af formidling, er de enkle spørgsmål: Hvilke tre ideer skal publikum kunne tage med hjem fra oplevelsen af denne udstilling - og hvilke genstande eller didaktiske elementer i udstillingen vil hjælpe dette på vej? (Samis \& Pau, p. 155).

Det er brugbare råd til arbejdet med besøgsoplevelser, digitale medier og publikumsdeltagelse: Deltagelse skal understøttes og tænkes strategisk. Aktivitetsformer skal tilrettelægges, så det er overskueligt og håndgribeligt for publikum at deltage - med eller uden digitale katalysatorer.

Connie Suabo

Adjunkt, ph.d. Institut for Miljø, Samfund og Rumlig Forandring Roskilde Universitet csvabo@ruc.dk 